\title{
$\gamma$-カメラ・レノグラムの臨床的研究
}

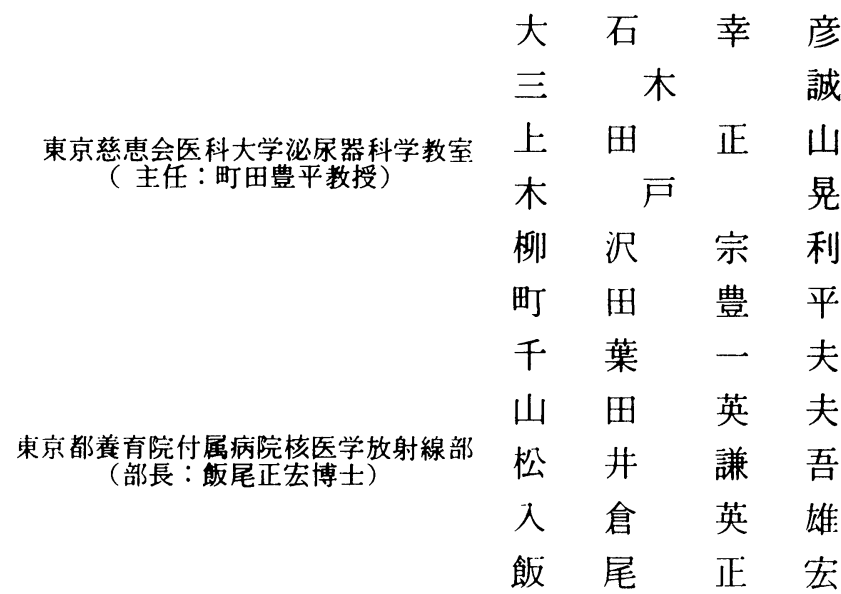

\section{CLINICAL STUDY ON GAMMA CAMERA RENOGRAPHY}

Yukihiko Ohishi, Makoto Miki, Masataka Ueda, Akira Kido, Munetoshi Yanagisawa and Toyohei Machida

Department of Urology, The Jikei University School of Medicine, Tokyo, Japan

(Director: Prof. Toyohei Machida)

Kazuo Chiba, Hideo Yamada, Kengo Matsui, Hideo Irikura

and Masahiro Iio

Department of Nuclear Medicine and Radiological Science, Tokyo

Metropolitan Geriatric Hospital, Tokyo, Japan

(Director: Masahiro Iio)

Recently, the prevalence of the gamma camera has provided in urology with increased availability of gamma camera renography using various radiopharmaceuticals. Using gamma camera renal images can be obtained in a few minutes and also renograms are depicted by setting regions of interests (ROI) on the each kidney simultaneously. Therefore, one of many advantages of the gamma camera renography is that information on time-course renal function and morphology can be obtained simultaneously.

The clinical study was made on renography by ${ }^{90 \mathrm{~m}} \mathrm{Tc}-(\mathrm{Sn}) \mathrm{DTPA}$.

One hundred and eighty-six cases (96 males and 90 females) were examined with age of 11 to 97 years old (mean 60.2 years old).

In this study, Searle Pho/Gamma HP gamma camera was used with Data Store Play Back System, Diverging collimator and $32 \mathrm{KW}$ Nova Computer System.

The radiopharmaceuticals used were 2 to $10 \mathrm{mCi}$ of ${ }^{99 \mathrm{~m}} \mathrm{Tc}$-(Sn)DTPA and $300 \mu \mathrm{Ci}$ of ${ }^{131} \mathrm{I}$-Hippuran.

The results were as follows:

1) Although ${ }^{99 m} \mathrm{Tc}$-(Sn)DTPA is a GFR substance, its renal clearance is relatively fast. Therefore, ${ }^{99 m} \mathrm{Tc}$-(Sn)DTPA could be applied for dynamic renal study similar to ${ }^{181}$ I-Hippuran.

2) As gamma camera renograms was depicted after ROI setting on the each kidney, contribution 
from the extrarenal activity could be excluded. Simultaneous gamma camera images also served to obtain information of renal morphology and the manner of urine flow in the upper urinary tract.

3) ${ }^{99 m} \mathrm{Tc}-(\mathrm{Sn}) \mathrm{DTPA}$ renogram was found to be useful to differentiate the obstructive renal disease, when ${ }^{131}$ I-Hippuran renogram showed obstructive pattern in patients with parenchymal disease.

4) In parenchymal renal disease ${ }^{99 \mathrm{~m}} \mathrm{Tc}-(\mathrm{Sn}) \mathrm{DTPA}$ renogram disclosed pathological changes earlier than ${ }^{131}$ I-Hippuran renogram.

In obstructive renal disease involving the upper urinary tract, in spite of the apparent improvement of ${ }^{181} \mathrm{I}$-Hippuran renogram, ${ }^{99 \mathrm{~m}} \mathrm{Tc}$ - $(\mathrm{Sn}) \mathrm{DTPA}$ renogram still revealed the latest state of disease. Therefore, ${ }^{90 \mathrm{~m}} \mathrm{Tc}-(\mathrm{Sn})$ DTPA renogram showed more sensitivity in detecting both obstructive and parenchymal renal disease and provide clinicians with useful aid in the follow up studies of operated cases with, for example, obstructive uropathy in the upper urinary tract.

In summary, ${ }^{99 \mathrm{~m}} \mathrm{Tc}$-(Sn)DTPA gamma camera study is found to be an useful aid in clinical urology. This technique is atraumatic, simple and safe even on such cases with poor risk, aged or children.

\section{緒言}

最近， $\gamma$-カメラの利用が一般化するとともに， $\gamma$-カメ ラを用いたレノグラフィーも開発されてきた メラを利用すると腎イメージは短時間内に撮影可能で, また関心領域 (regions of interest, 以下 ROI と略す) をそれぞれの腎またはその特定部位に設定することによ クレノグラムが記録でき，腎の形態と機能の病態生理を 両面から同時に経時的に知ることができる。

腎動態機能検查用の放射性医薬品としては現在腎血漿 流量（以下 RPF と略す）測定物質である ${ }^{131} I$-Hippuran が広く臨床的に応用され，系球体濾過量（以下GFR と略 す）湘定物質の代表としては Iodothalamic acid が用い られている。しかし， ${ }^{131} \mathrm{I}$ 標識化合物は $\gamma$-カメラのクリ スタルが $1 / 2$ " と薄いため, 効率が悪いこと, そのため カメラにより明膫な像を経時的に短時間内で得るには相 当大量投与を必要とすることから ィーには必ずしも適当ではない(4)。ことに Iodothalamic acid は尿中排泄も洋く動態計測を目的とする $\gamma$-カメラ・ レノグラフィーには適していない。

著者らは今回 $\gamma$-カメラを利用し新しい放射性医薬品 ${ }^{99 \mathrm{~m}} \mathrm{Tc}$ - $(\mathrm{Sn})$ Diethylenetriaminepentaacetic acid (以下.99m Tc-(Sn) DTPA と略す) を用いた腎機能検査法の有用性 についての臨床的検討を行なつた。

\section{対象と方法}

対象 : 慈恵医大泌尿器科と東京都盖育院付属病院の全 186症例にたいし 358回のレノグラフィーを実施した。 186症例中の 154 例 $~^{99_{\mathrm{m}} \mathrm{Tc}} \mathrm{C}-(\mathrm{Sn})$ DTPA と $^{131} \mathrm{I}$-Hippuran の両放射性医薬品投与によるレノグラフィーを 326回施 行し比較検討した。症例の内訳は男子96例，女子90例， 年齢 11 歳 97 歳，平均 60.2 歳であつた。対象疾患は腎尿
路疾患 111例，高血圧症25例，心血管系疾患22例，その 他28例であつた。

r-カメラ・レノグラムの装置と方法： $\gamma$-カメラはSea rle 製 Pho/Gamma HP, Data Store Play Back SystemNova 32KW Computer System, コリメーター (collimator) は1261hole diverging 型, レートメーター（ratemater）は島津製を用いた。

ケーカメラ・レノグラムの撮影の原理は Fig. I に示す

Fig. 1 Diagram of the present methods.

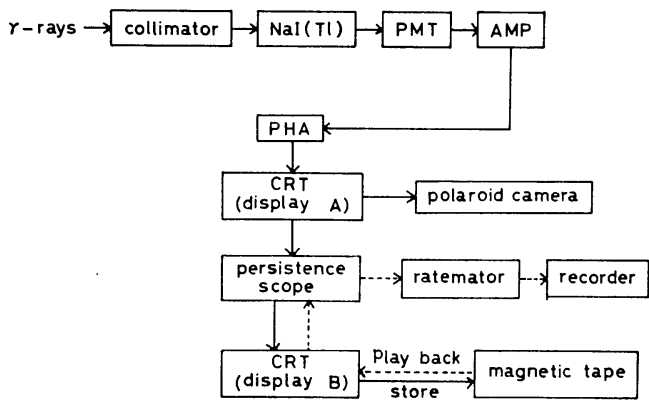

如く，生体内腎に集積した放射能はコリメーターを介し てクリスタル $(\mathrm{NaI}(\mathrm{Tl}))$ に入射し蛍光を発する。こ の蛍光を31本の光電子増倍管 (PMT) で増幅, 更に増 幅器 (AMP) で増幅した後, 波高分析器 (PHA) で光 電子ピークを捉え，またマトリックスを介して位置を計 算したのち 粴点としてブラウン管 (CRT) 上に display される．よいイメージをうる為にはこの輝点が十分な像 を結ぶまで一定時間集積，主としてポラロイドカメラで 撮影するものである．放射能分布の時間的経過は磁気テ ープ（VTR）にも収睩される．磁気テープに収録された 
Fig. 2 Gamma camera renal images and ROI setting for gamma camera renography.
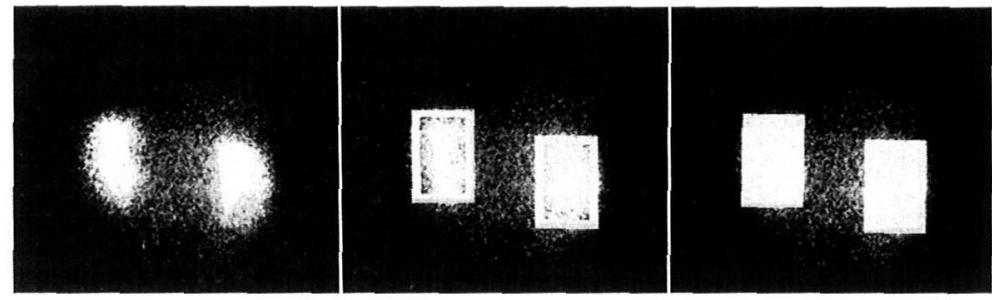

情報はテープを playback することで再現でき，モニタ 一 (persistence scope) 上で腎の ROI を設定，この部以 外の放射能をカットし, ROI 内のみの放射能の時間的推 䔟をレノグラムとしてレコーダー上に連続的に描記させ る.な拈, ROIの設定に当つては Fig. 2 に示す如くモニ ター上の腎イメージで正確に両腎の占める領域を決めて elertronic window を重複することにより正確に両腎の 夫々よりの放射能推移をレノグラムとして記録できる。

$\gamma$-カメラ・レノグラムの撮影方法は検查30分前に 200 〜300ml の水負荷を行ない, 坐位で, 背方から撮影し た. 情報はいつたん磁気テープに収録, 後にテープを playback し, 左右両腎部に ROI を設定, レートメータ 一を介し $\boldsymbol{\gamma}$ 一カメラ・レノグラムを記録解析した。検查は ${ }^{99 \mathrm{~m}} \mathrm{Tc}$-(Sn) DTPA $2 \mathrm{mCi}$ を使用したときは20分間, ${ }^{131} \mathrm{I}$ hippuran $300 \mu \mathrm{Ci}$ では15分間で行なつた。腎イメージは 情報を磁気テープに収録と同時にポラロイドカメラで撮

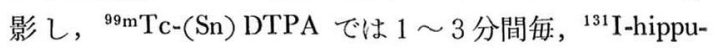
ran では 3 分間每に経時的に撮影した。な拈,レノグラ 么の描出条件は時定数 10 秒, チャート速度 $10 \mathrm{~mm} / \mathrm{min}$, レンヂは ${ }^{99 \mathrm{~m}} \mathrm{Tc}-(\mathrm{Sn})$ DTPA では 200 500cps, ${ }^{131} \mathrm{I}-\mathrm{Hip}-$ puran では20〜50cps である。また,レノグラムのみな らずラジオアイソトープ (radioisotope, 以下 RI と略す) 腎アンギオグラフィーを必要とするときは， ${ }^{99 \mathrm{~m} T c-(\mathrm{Sn})}$ DTPA $10 \mathrm{mCi}$ bolus として肘静脈より静注, 10秒〜 40 秒まで 5 秒毎に血管相 (vascular phase) を, 以後引き続 き15〜20分まで $2 \sim 3$ 分毎に機能相 (functional phase) の経時的イメージを撮影した。同時に実施したレノグラ ムの描出方法は前述の如くであるが，レンヂは $1 \mathrm{~K} \sim 2$ K cps である.

放射性医薬品：キレート物質である Diethylenetriaminepentaacetic acid (DTPA) は, 化学的に安定で高い 化学的結合能を持ら, 重金属とキレートを形成し，その 區とんどが腎糸球体から排泄されることから，種々の 核種で摽識されたDTPA が GFR の測定に陚用されてき
$た^{5)}$.

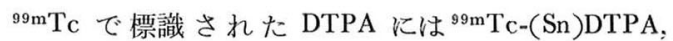

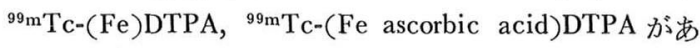
る.これら物質の血墏からの消失速度や腎からの排泄速

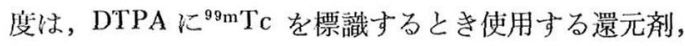
錫, 鉄, 鉄アスコルビン酸により異なる ${ }^{6)} \cdot{ }^{99} \mathrm{~m} \mathrm{Tc}-(\mathrm{Sn})$ DTPA は95\%まで真のキレートで, 安定で, 主として 腎系球体から単独で排泄され, 他の特定の集積葴器もな い物質であり，GFR 物質としては腎よりの排泄は非常

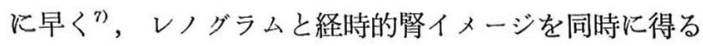

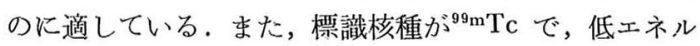
ギー, 短半減期で $\beta$ 線がないので被検者の被曝線量は少 なく ${ }^{8)}$ 大量投与が可能で $\boldsymbol{\gamma}$-カメラに適している.

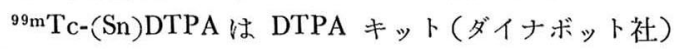
によつて調製した。キットは $\mathrm{Na}_{5}$ DTPA $5 \mathrm{mg}, \mathrm{SnCl}_{2} 0.25$ mgを含も減菌バイアルで， $\mathrm{pH}$ 4.0である。このバイアル に $2 \sim 8 \mathrm{ml}$ の $^{99} \mathrm{TcO}_{4}$-液を加え 1 分間振燙, 混和する 簡単な操作で確実に調製できる ${ }^{9)}$.

\section{臨床成績}

1）正常腎機能の $\gamma$-カメラ・レノグラム ${ }^{99 \mathrm{~m}} \mathrm{Tc}$-(Sn)DTPA $\gamma$-カメラ・レノグすムの最高值到

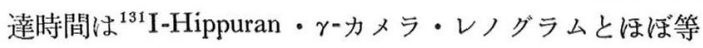
しく 5 分以内にあるが，第 2 相の上昇勾配は ${ }^{131} \mathrm{I}-\mathrm{Hippu}$ ranよりるやや少なく, 第 3 相は ${ }^{131} \mathrm{I}-$ Hippuran より全体 にゆるやかな曲線を描きながら比較的早く排泄される。 腎イメージでは, ${ }^{99 m}$ Tc- (Sn) DTPA は $3 \sim 6$ 分像が最 も鮮明で, その後徐々にうすくなるが検查終了時の20分 でも比較鮮明な像として得られる。これに反し， ${ }^{131} \mathrm{I}$ Hippuran のイメージは0〜3 分が最も鮮明で以後急激 に不鮮明となり，15分では不明膫となる。腎のイメー シは総体的に ${ }^{99 \mathrm{~m}} \mathrm{Tc}-(\mathrm{Sn})$ DTPA (2mCi) が ${ }^{131} \mathrm{I}-$ Hippuran $(300 \mu \mathrm{Ci})$ 飞優つている.

症例 1 . 33歳, 男子, 総腎機能正常.

Fig. 3 は $^{131}$ I-Hippuran と ${ }^{99 \mathrm{~m}} \mathrm{Tc}$-(Sn) DTPA による正 
Fig. 3 Normal gamma cammera renograms (case 1).

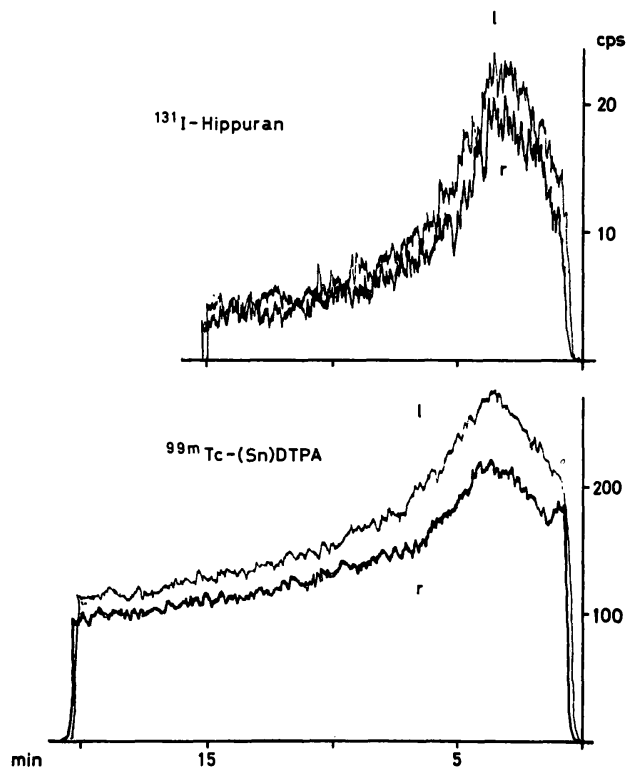

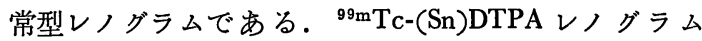

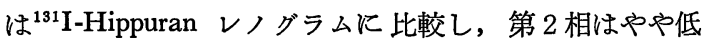
く, 第 3 相は全体にゆるやかな曲線を示すが，統計精度

Fig. 4 Left hydronephrosis (case 2).

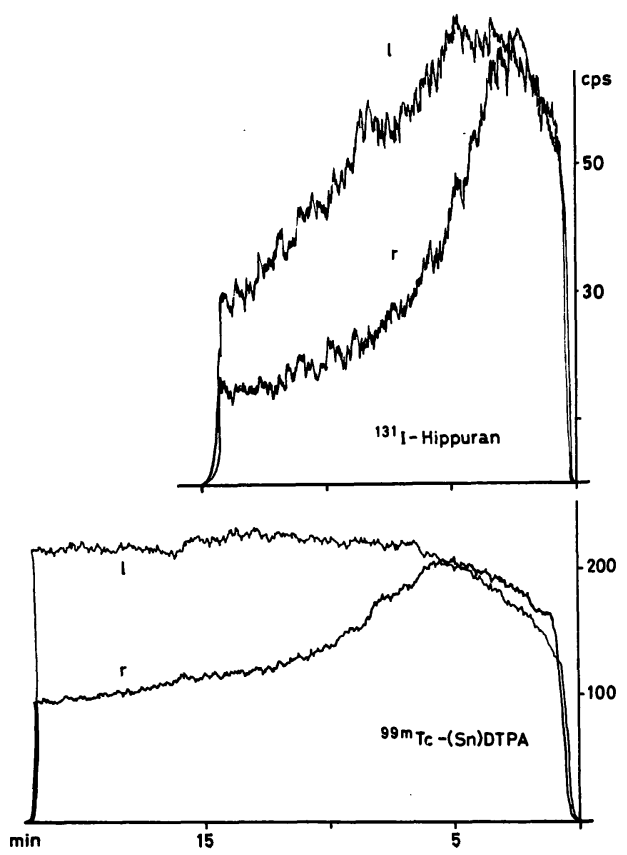

は優れている。

2）閉塞性尿路障害の $\gamma$-カメラ・レノグラム 閉塞性尿路障害時のレノグラムは最高值到達時間の延 長と第 2 相, 第 3 相の延長緩徐化が特長とされている.

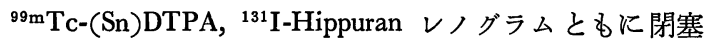
型を呈したものは35例 (偏側性26例, 両側性 9 例) であ つたが，その代表例を次に示す。

症例 2.32 歳, 男子, 左間歇的水腎症.

主訴は左側腹部痛, IVP で軽度の左水腎症を認めた。 総腎機能検査成績 は BUN $15 \mathrm{mg} / \mathrm{dl}, \mathrm{PSP}$ 試験15分值25 $\% ， 120$ 分値 $97 \%$ と正常範囲内. ${ }^{131} \mathrm{I}$-Hippuran レノグラ ムは (Fig. 4上) 左腎で第 2 相の延長, 第 3 相の遅延

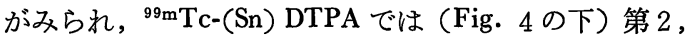
3 相の変化がより顕著にみられる. Fig. 5 は81日後に 再検したさいの両者のレヒグラムである. ${ }^{131}$ I-Hippuran は正常型に回復しているが， ${ }^{99 m} \mathrm{Tc}$-(Sn) DTPA はなお第 3 相の遅延がみられる. 本症例の初回検査時の $\gamma$-カメ ラ袩イメージを Fig. 6 に示したがレノグラムの推移が

Fig. 5 Improved left hydronephrosis(same case as Fig. 2)

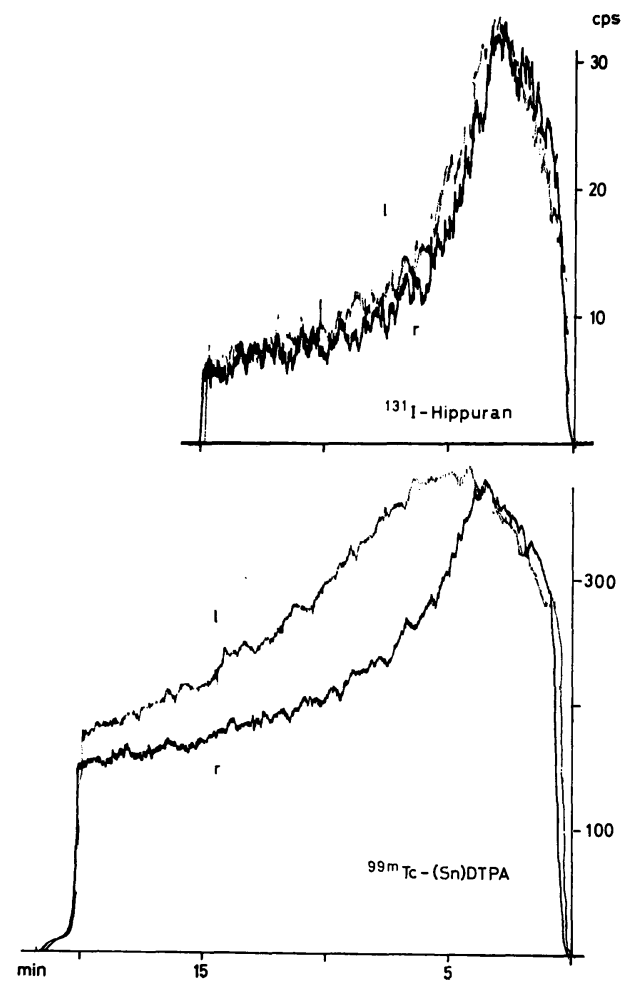


Fig. 6 Sequential renal images of case 2

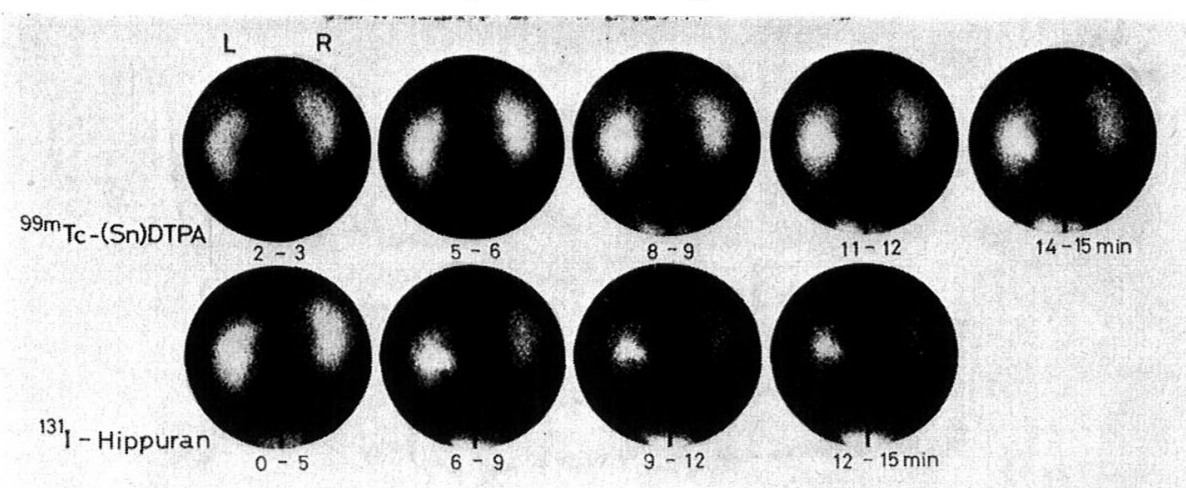

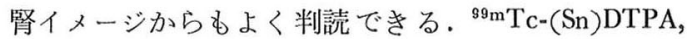
${ }^{131}$ I-Hippuran はともに時間の経過とともに左腎需部に 放射能が集積する像がみられ, 両者に RI の分布範四, 集積時間のずれが多少あることもわかる.

症例 3.19 歳, 女子, 左先天性水腎症.

主訴は左側腹部の疝痛, DIP などで左腎需尿管移行 部の狭窄による先天性水腎症と診断した. 総腎機能検査 は BUN $12 \mathrm{mg} / \mathrm{dl}$, クレアチニン $0.8 \mathrm{mg} / \mathrm{dl}$, GFR $90 \mathrm{ml} / \mathrm{min}$,

Fig. 7 Gamma camera renograms of the case 3 (before operation)

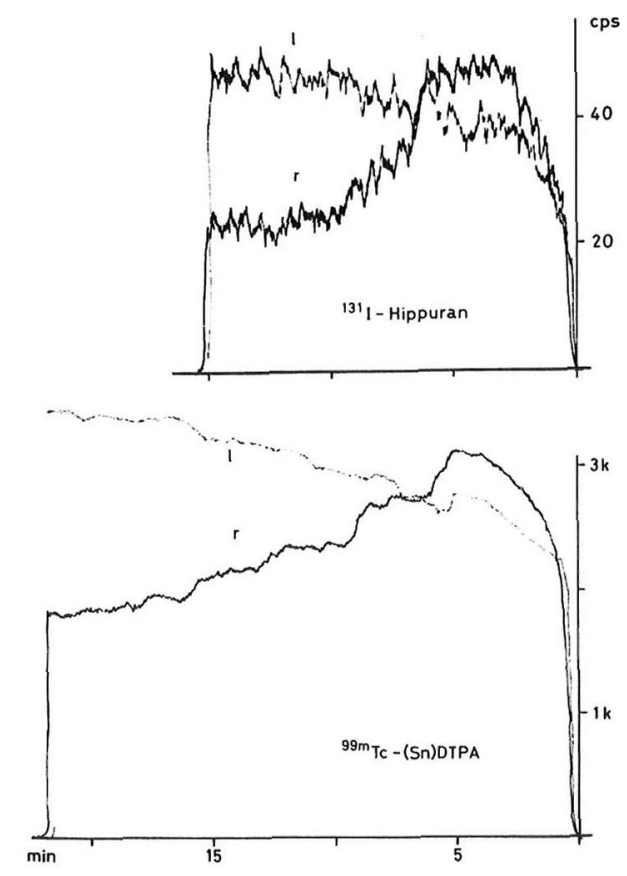

PSP 試験15分值25\%，120分值89\%と正常範囲内であつ た.Fig. 7 に示した両レノグラムは左側に第 3 相の下 降がみられない，Fig. 8 は同症例に左腎盖形成術を施

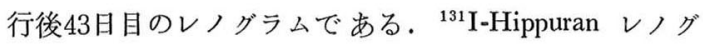
ラムではわずかに第 $2 ， 3$ 相の遅延が認められるが，術 前に比して明らかに改善がみられる。しかし, ${ }^{99 \mathrm{~m} T c-}$

Fig. 8 Gamma camera renograms of the case 3 (43 days after operation)
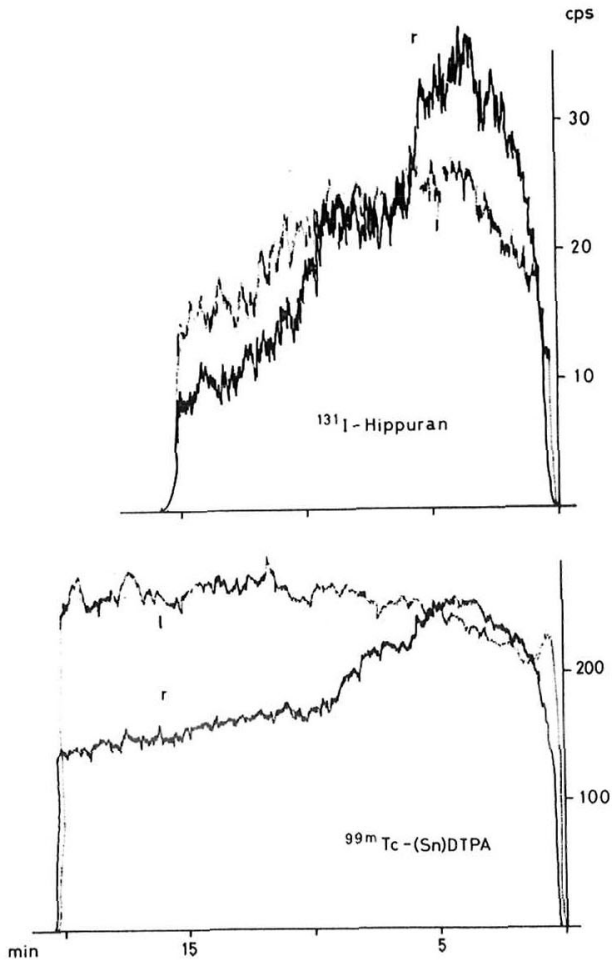
(Sn)DTPAレノグラムは未だ術前とほぼ同様閉塞型を

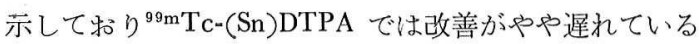
ことが分る. Fig. 9 そ術前, Fig. 10飞術後のDIPを示 したが形態的には術後は改善している。

3）実質性腎機能障菁の

Fig. 9 DIP of case 3 (before operation).

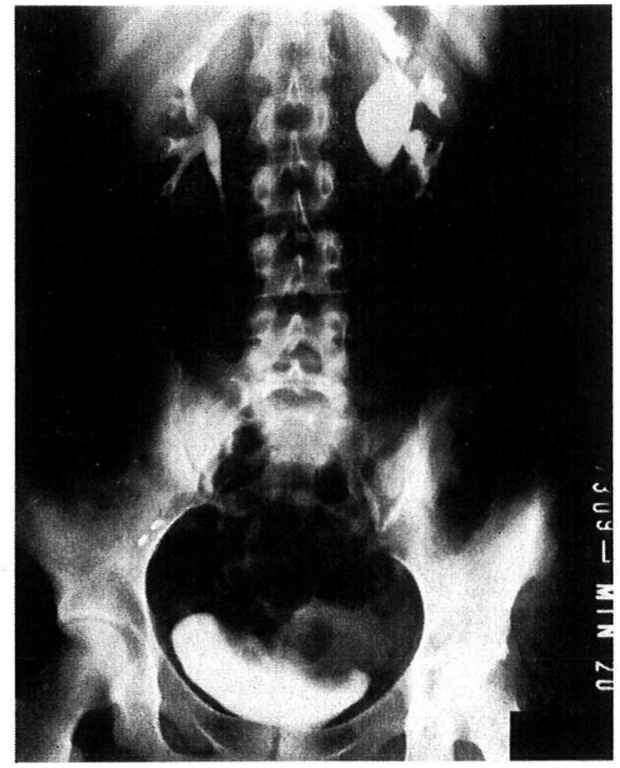

Fig. 10 DIP of case 3 (after operation)

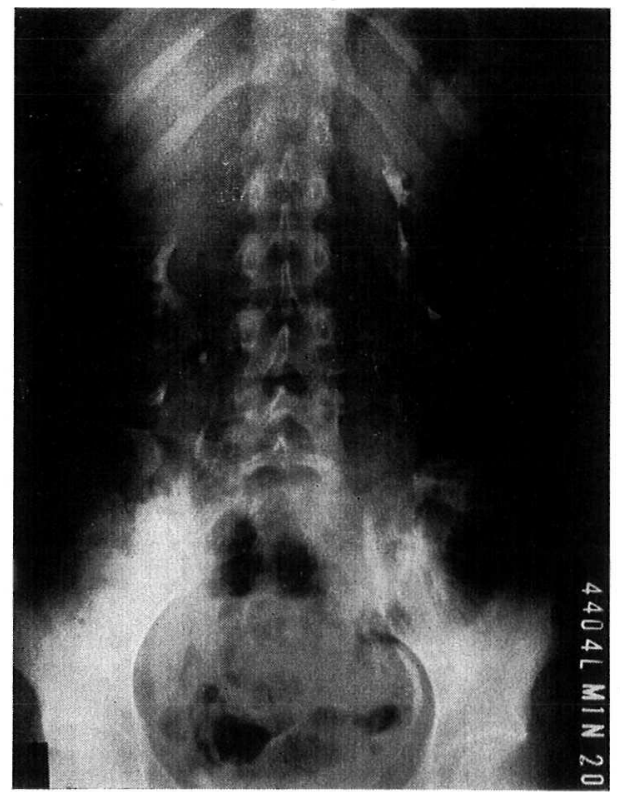

腎実質障害すなわら非閉塞性実質性腎障害を示したも のは60症例であつた。慢性先質性腎疾患による高度腎機 能障害例では，两レノグラムはともに平担な型を示し た。しかし，高度に腎機能が障害された例を除くと，

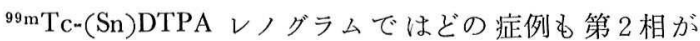
消失平低化し，第 3 相に移行するのにかかわらず， ${ }^{131} \mathrm{I}$ Hippuran レノグラムでは第 2 , 第 3 相の平低, 遅延化を 呈するものと, 第 2 , 第 3 相で閉塞型を示す 2 つ型式 が涩められた。後者の型すなわら, 実質性腎障害であり ながら閉塞型レノグラムを是した例は10例みられた。 $\gamma$ カメラでこの型の腎イメージを観察すると, ${ }^{99 \mathrm{~m}} \mathrm{Tc}$ - ( Sn) DTPA, ${ }^{131}$ I-Hippuran の経時的腎イメージは腎機能の低 下に伴い back ground が高くなり不鮮明となる。しか し, ${ }^{131} \mathrm{I}-$ Hippuran レノグラムが閉塞型を示するのは時 間経過とともに腎影が鮮明となり ${ }^{99 \mathrm{~m}} \mathrm{Tc}$ - $(\mathrm{Sn}) \mathrm{DTPA} の$ イメージよりも優れている所見であつた。

症例 4.23歳, 女子, 慢性糸球体腎炎。

諸検查成績は BUN $20 \mathrm{mg} / \mathrm{dl}$, クレアチニン $1.2 \mathrm{mg} / \mathrm{dl}$, GFR $80 \mathrm{ml} / \mathrm{min}$, 尿蛋白 (冊), 硝子様円柱 $5 \sim 6$ 二/数視 野, PSP 試験15分值30\%, 血圧 110/80 mmHg, IVP 正常, 腎生検所見は慢性涨慢性系球体腎炎であつた。 Fig. 11 に両レノグラムを示した。 ${ }^{131}$ I-Hippuran レノグラムは ほぼ正常であるが，99mTc-(Sn)DTPA では第2相をほ とんど形成せず第 3 相に移行し, 明らかに異常レノグラ ムを呈した。

症例 5.75歳, 女子, 腎硬化症

Fig. 11 Gamma camera renograms of case 4 .

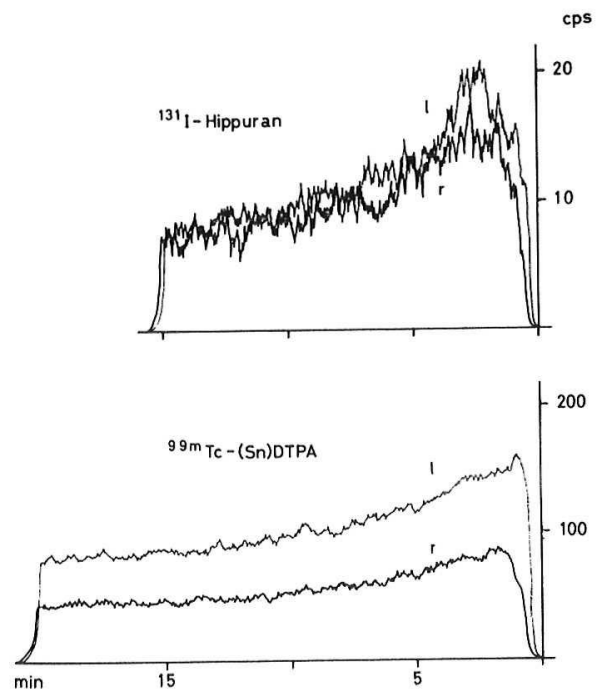


Fig. 12 Gamma camera renograms of case 5 .

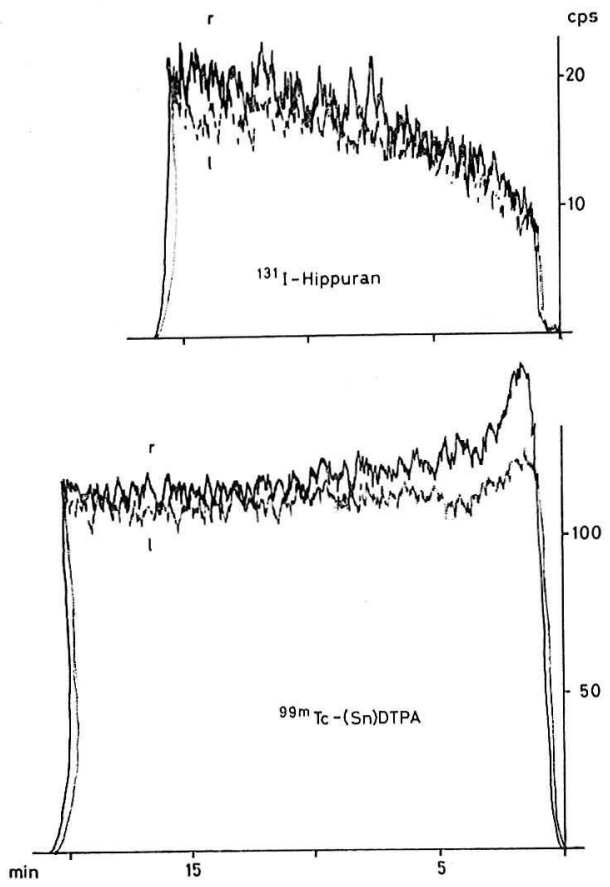

主訴は高血坐 (200/100 mm Hg), 尿蛋白 (卅), 浮腫で, 総腎機能検査は BUN $31.8 \mathrm{mg} / \mathrm{dl}$, クレアチニン $2.53 \mathrm{mg} / \mathrm{dl}$ フィシュバーグ 濃縮試験1021, PSP 試験 15 分值 $5 \%$, 120分值25\%と低下しており，眼底はKW 4 度であっ た. Fig. 12に示す如く ${ }^{131}$ I-Hippuran レノグラムは閉塞

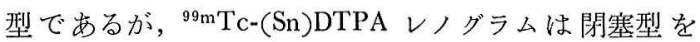
示さない，Fig. 13は同一症例 の ${ }^{131} \mathrm{I}$-Hippuran $亡^{99 \mathrm{~m} T \mathrm{~T}-}$ (Sn)DTPA の経時的腎イメージである. ${ }^{131} \mathrm{I}-$ Hippuran では時間経過とともに放射能は腎実質に摄取され，腎イ
メージは鮮明となる。また， ${ }^{99} \mathrm{~m} \mathrm{Tc}-(\mathrm{Sn})$ DTPA でも腎盂 部への放射能集積はみられない，このことからこの症例 は実質性腎障害であることが推定される．本症は剖検で 尿路に通過障害を認めず，腎の組織所見は腎硬化症であ つた。

4）部分的腎機能障害の $\gamma$-カメラ・レノグラム

部分的腎機能障害は腎癌, 腎のう腫, 腎結核, 腎梗塞 などの症例に主にみられた。これらの症例の部分的機能 診断には， ${ }^{99} \mathrm{~m} \mathrm{Tc}-(\mathrm{Sn}) \mathrm{DTPA}$ にる RI 腎アンギオグラ フィーが有用であつた。また，障害部と正常部にそれぞ れ ROI を設定することにより両部の機能差が部分的レ ノグラム (regional renogram) として描記できた。

症例 6 . 65歳, 男子, 右腎癌.

主訴は無症候性全血尿, 膀胱鏡で右尿管口からの血尿 を確認したＩVP，RPで右腎上極に $8.0 \times 6.0 \mathrm{~cm}$ の space occupying lesion とこれに接する腎杯の延長と变形を認 めた。腎動脈撮影 (Fig. 14A) では，同部に腫瘍血管 を認めた。 ${ }^{99 \mathrm{~m} T c-(\mathrm{Sn}) \mathrm{DTPA} に よ る \mathrm{RI}}$ 腎アンギオグラ フィーでは, 15〜20秒の血管相イメージ (Fig. 14B) の 如く，右腎上極（腫瘍部分）は血流を認めたか，機能相 イメージ (Fig. 14C) では摂取率が低く欠損像となつ た、 ケーカメラ・レノグラムでは (Fig. 15A), 左は正常 型，右は第 2 相の遅延を示した. ROI を腫瘍部分 (a)と 正常部分 (b)とに設定すると両部のレノグラムは Fig. 15 B に示す如くなつた。すなわち，(a)部分では第 1 相 は正常で，第 2 相は火如し第 3 相に移行与る型, (b)部 分は正常型を示した. Fig. $15 \mathrm{C}$ は (a)部分と (b)部分 の第 1 相を秒単位で詳細に描記したものである。

\section{考按}

$\gamma$-カメラ・レノグラムとは，腎での放射能動態の情報

Fig. 13 Sequential renal images of case 5 .

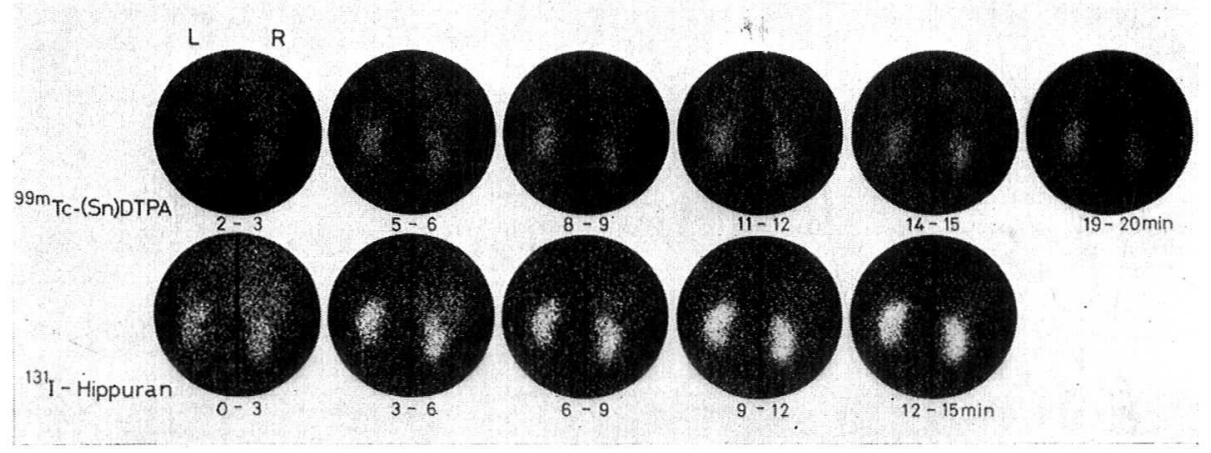


Fig. 14 Right renal carcinoma (case 6).

A) Selective righ renal arteriogram.

B) Vascular phase image $(15-20 \mathrm{sec})$ by ${ }^{99 \mathrm{~m} T c}-(\mathrm{Sn}) \mathrm{DTPA}$.

C) Functional phase image (1-3 min) by ${ }^{99 \mathrm{~m}} \mathrm{Tc}-(\mathrm{Sn}) \mathrm{DTPA}$.
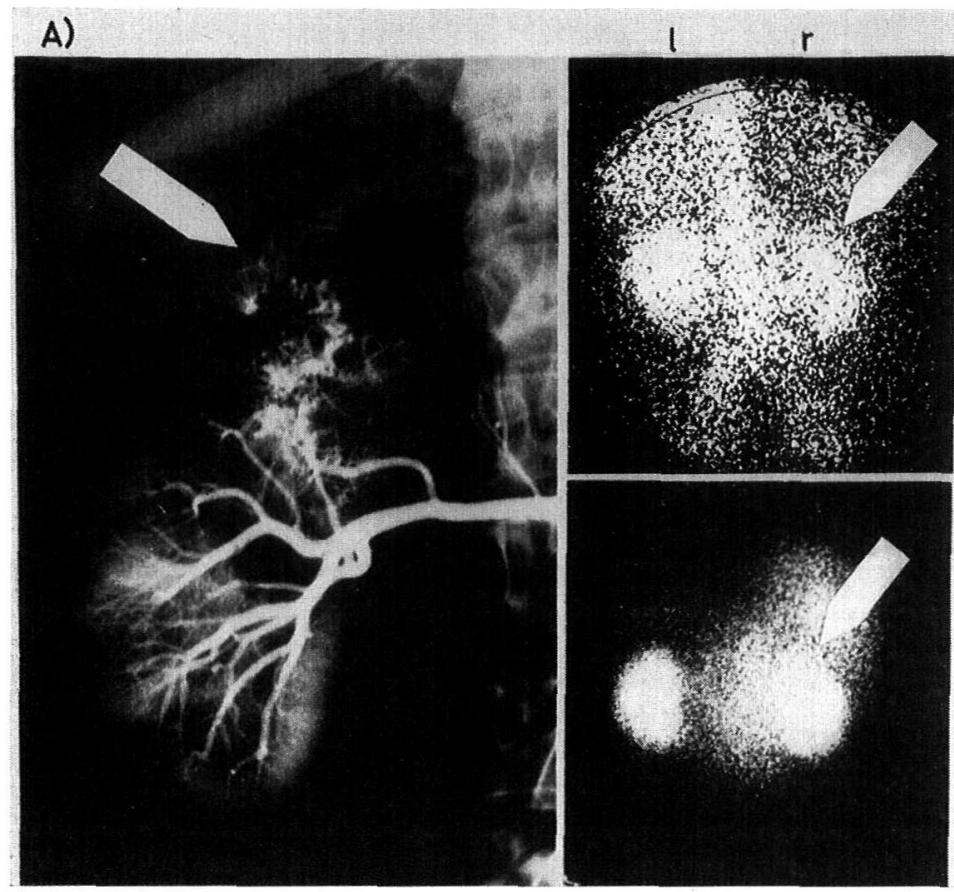

B)

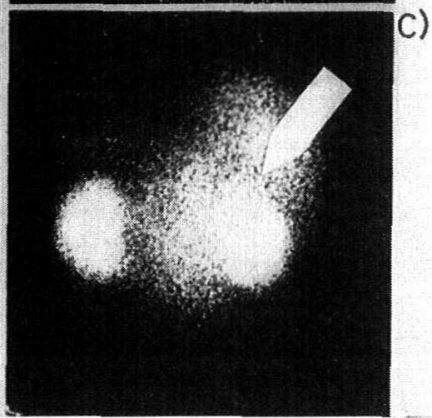

Fig. 15 Gamma camera renograms of case 6.

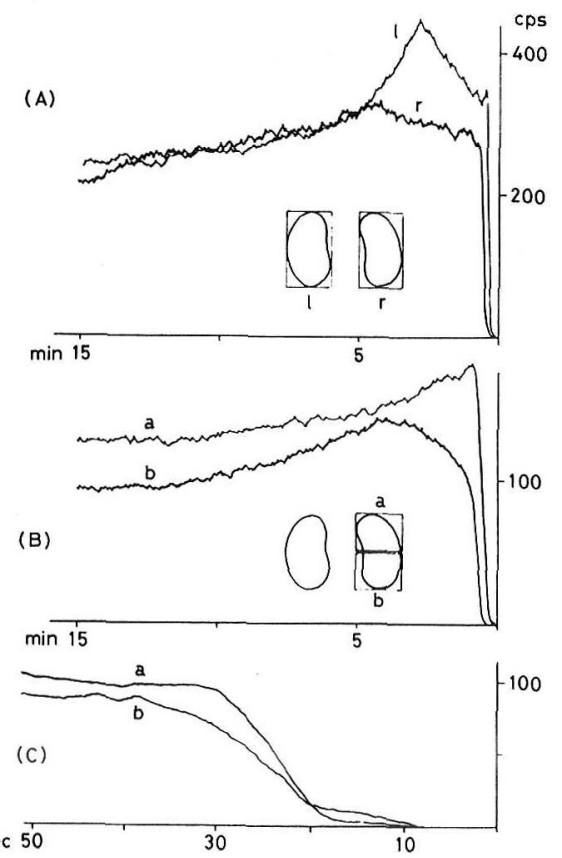

を全て磁気テープに収録し，後にテープを playbackす ることにより，収録された情報をモニタ一上で腎のイメ 一ジとして再現し, ここで左右雨腎部に ROI を設定し, ROI のみの 放射能をレノグラムとして描記させたもの である. 従つてこのようにして得られたレノグラムは， 幾何学的な腎部指定区域からのみの放射能を計測してい ることになり, 在来のレノグラム装置を用いた方法と比 較して位置のずれは除外でき，また，腹部大動脈や腎以 外の放射能の影響を受けない利点がある。さらに情報 の収録と同時に経時的な㛑, 上部尿路のイメージも得ら れ, 形態的情報も求められるので診断的価值が高くな る.

このような方法で得られた ${ }^{99 \mathrm{~m}} \mathrm{Tc}$ - $(\mathrm{Sn}) \mathrm{DTPA} と^{121} \mathrm{I}$ Hippuran の $\gamma$-カメラ・レノグラムはそれぞれ腎での慓 識化合物の薬㨈動態を示す曲線として描かれる。つまり ${ }^{99} \mathrm{~m}$ Tc-(Sn)DTPA と ${ }^{131}$ I-Hippuran の腎での摂取排泄動 態によつて雨者に差が現われる。著者らが正常腎機能症

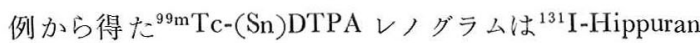
レノグラムより最高值到達時間の若干の延長, 第 3 相の 
緩徐な減衰を示した. Konikowski $ら^{10)} は^{14} \mathrm{C}-$ Inulin クリ アランス值を1.0としたときの ${ }^{131} \mathrm{I}$-Hippuran, ${ }^{99} \mathrm{~m} \mathrm{Tc}-(\mathrm{Sn})$ DTPA, ${ }^{99 \mathrm{~m}} \mathrm{Tc}$-(Fe)DTPA, ${ }^{99_{\mathrm{m}} \mathrm{Tc}}$-(Fe ascorbic acid) DTPA などのクリアランス比を求め, ${ }^{99} \mathrm{~m}$ Tc-(Sn)DTPA は ${ }^{131} \mathrm{I}$-Hippuran の 3.4に次いで2.48と早く，一部尿細 管からの排泄もあると報告している。これらの事実より ${ }^{99} \mathrm{mTc}-(\mathrm{Sn}) \mathrm{DTPA}$ はレノグラム用の放射性医薬品として 利用できるといえる。

水腎症いわゆる obstructive uropathy にみられる Tc-(Sn)DTPA レノグラムと ${ }^{131} \mathrm{I}-H$ ippuran レノグラムは ともに従来から指摘されているパターンを示した。両者 の間にパターン上の差異はないが腎実質機能の存在程度 と尿流障害の程度によつて特に第 3 相の出現に変化が あるが，パターンとしての本質的な違いはないと解釈し てよい、また， acute obstructive uropathy では第 3 相の 上昇が ${ }^{99 \mathrm{~m} T c}$ - $(\mathrm{Sn}) \mathrm{DTPA}$ よりも著明にみられるのは ${ }^{131} \mathrm{I}-$ Hippuran の排泄速度の早さによるものが主体となるた め現象と解䣋される。

腎実質障害時には一般に第 2 相の平低化と第 3 相の遅 延がみらることはすでに多くの人が指摘している。と

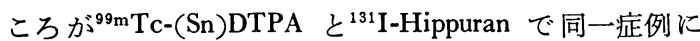
$\gamma$-カメラ・レノグラムを施行しその曲線を解析すると, 腎実質障害であるにも拘らず ${ }^{131}$ I-Hippuran レノグラム のみが閉塞型レノグラムを示す例があること，また， ${ }^{131}$ I-Hippuran では正常であるにも拘らず99mTc-(Sn)DT PA で異常パターンを示す例などに気付いた，腎実質障 害時の ${ }^{131}$ I-Hippuran レノグラムに於ける閉塞型の出現 は症例 5 に示したが，この理由は尿細管機能障害による 同部での ${ }^{131}$ I-Hippuran の transit time の遅延にあると 思われる. しかし， ${ }^{99} \mathrm{~m} \mathrm{Tc}-(\mathrm{Sn}) \mathrm{DTPA}$ は主として糸球 体より排泄されるため尿路通過障害がなければ閉塞型を 呈さないと解釈している。

Winter $^{11)}$ (1961)，Trinkle \& Kiser (1964) ${ }^{12)}$ は乏尿 性腎不全では ${ }^{131} \mathrm{I}-$ Hippuran レノグラムで閉塞性と実質 性腎疾患の鑑別ができると述べている。しかし Mayo $ら^{13)}$ （1971）の報告でもみられるように， ${ }^{131} I$-Hippuran レノグラムは腎尿路に閉塞がなくても閉塞型レノグラム を呈することがあり両疾患の鑑別が困難な場合もある. 閉塞型レノグラムは腎動脈から膀胱迄の放射能の通過時 間の遅延を反映しているので，上部尿路の通過障害にそ の原因があることが最も多い，しかし，尿路の通過障 害以外にも高度な腎動脈狭窄, ショック, 脱水 ${ }^{14)}$, 腎硬化 症, 系球体腎炎 ${ }^{15)}$, 移植腎の拒絶反応 ${ }^{16) 17)}$ でも閉塞型レ
ノグラムを呈することが知られている. Mayo ら ${ }^{13)}$ は急 性尿細管壊死の乏尿期打よび利尿期に入つても 5 週間に わたつて両側の閉塞型レノグラムを呈した 4 例を報告し ている．これらの症例では，ミオグロビン尿症による 1 例を除き，尿路の閉塞はなかつたといら．また，慢性腎 疾患による高度尿毒症のレノグラムは全く平担で, この 所見から ${ }^{131} \mathrm{I}-$ Hippuran レノグラムのみでも急性腎不全 との鑑別が可能だと述べている.

レノグラム曲線が全体に平担化するとき，レノグラム のみでは閉塞性腎障害か実質性腎障害かの鑑別ができな い場合もあり，このようなとき腎イメージを参考にする ことの必要性についてはすでに金子ら ${ }^{1)}$ や著者ら ${ }^{18)}$ 女指 摘している如くである。

症例 5 に示すように ${ }^{131} \mathrm{I}-$ Hippuran レノグラムが閉塞

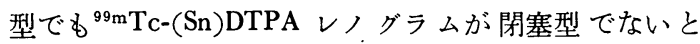
きはある程度閉塞性疾患は否定でさ，さらに同時に経時 的腎イメージを行ならと腎での放射能動態がより確実に 分り, 本法は急性腎不全腎の尿路閉塞性疾患と実質性腎 疾患の鑑別に役立つ.

以上述べた所見の他に， ${ }^{131}$ I-Hippuran では正常でも， ${ }^{99 \mathrm{~m}} \mathrm{~T} \mathrm{c}-(\mathrm{Sn})$ DTPA で異常が多く示されることもある. 症例 4 にこらした例を示したが，この例では糸球体機能 の低下が， ${ }^{131} \mathrm{I}$-Hippuran レノグラムに現われる以前に ${ }^{99} \mathrm{~m} T \mathrm{c}-(\mathrm{Sn}) \mathrm{DTPA} レ ノ ク ゙ ラ ム の$ 変化として認められた ことを示している.この点について久田ら ${ }^{19)}$ は次の如く 述べている. 即ち, ${ }^{131}$ I-Hippuran レノグラムは腎血流 量, 尿生成, 尿排出に関しては有効な情報を与えるが, GFR に関する情報には乏しく，腎疾患が存在していて も ${ }^{131}$ I-Hippuran レノグラムでは異常を発見できないこ

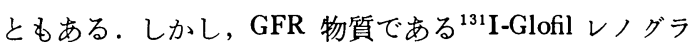
ムでは異常が明瞭に指摘できると報告している．一方， Hayes ( $^{20)}$ の動物実験による腎動脈狭窄例では, ${ }^{131} \mathrm{I}-$ Glofil レノグラムの変化は血流量の減少に比例して起こ るが, ${ }^{131} \mathrm{I}-$ Hippuran レノグラムは $25 \%$ 以上の血流減少 で初めてレノグラムの変化がみられ，有意の変化は50\% 以上血流が減少したとさみられたという．従つて腎疾患 のスクリーニング 検査として ${ }^{99 \mathrm{~m} T \mathrm{~T}-(\mathrm{Sn}) \mathrm{DTPA} レ ノ ク ゙ ラ ~}$ ムが ${ }^{131} I$-Hippuran レノグラムより優れている場合のあ ることを考えておく必要もある。

また，水腎症の回復過程のレノグラムに於ても ${ }^{99 \mathrm{~m} T \mathrm{c}-}$

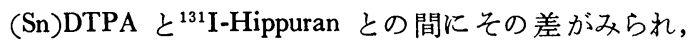
水腎症で腎機能の障害が進行したあとの機能の回復は尿 細管機能からの回復が先行していることを示している. 
Table 1 Characteristics of renogram pattern and sequential images by ${ }^{9 m_{\mathrm{m}}} \mathrm{Tc}-(\mathrm{Sn})$ DTPA and ${ }^{131}$ I-Hippuram.

\begin{tabular}{|c|c|c|c|c|}
\hline & \multicolumn{2}{|c|}{${ }^{99 \mathrm{~m}} \mathrm{Tc}-(\mathrm{Sn}) \mathrm{DTPA}$} & \multicolumn{2}{|c|}{${ }^{131}$ I-Hippuran } \\
\hline & Renogram & Image & Renogram & Image \\
\hline Normal & $\begin{array}{l}\text { Normal } \\
\text { (slower than } \\
\text { Hippuran) }\end{array}$ & $\begin{array}{l}\text { Image is most clear } \\
\text { as } 3 \text { to } 6 \mathrm{~min} \text { and then } \\
\text { becomes unclear } \\
\text { gradually after } 6 \mathrm{~min}\end{array}$ & Normal & $\begin{array}{l}\text { Image is most clear at } \\
3 \text { min, then becomes } \\
\text { unclear }\end{array}$ \\
\hline $\begin{array}{l}\text { Obstructive } \\
\text { uropathy }\end{array}$ & Obstructive pattern & $\begin{array}{l}\text { Radioactivity is } \\
\text { concentration into the } \\
\text { pelvis } \\
\quad \text { (Centralization) }\end{array}$ & Obstructive pattern & $\begin{array}{l}\text { Radioactivity is } \\
\text { concentration into the } \\
\text { pelvis } \\
\text { (Centralization) }\end{array}$ \\
\hline $\begin{array}{l}\text { Parenchymal } \\
\text { renal disease }\end{array}$ & $\begin{array}{l}\text { Second phase is } \\
\text { flat or disappear }\end{array}$ & $\begin{array}{l}\text { Homogenous } \\
\text { concentration }\end{array}$ & $\begin{array}{l}\text { (1) Second phase is } \\
\text { flat and } 3 \text { rd phase is } \\
\text { delayed } \\
\text { (2) Obstructive } \\
\text { pattern }\end{array}$ & $\begin{array}{l}\text { Homogenous } \\
\quad \text { concentration } \\
\rightarrow \text { The most clear image } \\
\text { is obtained at late } \\
\text { stage } \\
\rightarrow \text { Image is obtained } \\
\text { along with time } \\
\text { elapsed }\end{array}$ \\
\hline $\begin{array}{l}\text { Renovascular } \\
\text { hypertension }\end{array}$ & $\begin{array}{l}\text { Affected kidney } \\
\text { shows flat and } \\
\text { delayed } 2 \text { nd phase }\end{array}$ & $\begin{array}{l}\text { Affected kidney } \\
\text { accumulates less } \\
\text { activity with } \\
\text { homogenous } \\
\text { distribution }\end{array}$ & $\begin{array}{l}\text { Affected kidney shows } \\
\text { flat and delayed } 2 \text { nd } \\
\text { phase but sensitivity } \\
\text { is lower than }{ }^{99 \mathrm{~m} T c-} \\
\text { (Sn) DTPA }\end{array}$ & $\begin{array}{l}\text { Same as }{ }^{99 m} \mathrm{Tc}-(\mathrm{Sn}) \\
\text { DTPA }\end{array}$ \\
\hline
\end{tabular}

症例 2 , 症例 3 はそれらの事実を示するのである.

rーカメラ・レノグラムが得られるとき同時に描出でき る経時的腎イメージは，その形態的推移と合せて，RI の分布移行や RI の摂取率の変化も読みとれる. 即ち, レノグラムが閉塞型を示しても実質に均等に分布した実 質性腎障害か，腎盂腎杯に貯留した閉塞性腎障害かは腎 の経時的イメージから直ちに読みとれる。また，部分的 欠損像の有無, その部の RI の時間的集積の変化なども 観察される．部分的腎機能障害の実例は症例 6 の腎癌例 で示したが，RI 腎アンギオグラフィーは簡便な優れた 腎の space occupying lesion の鑑別診断法で，また space occupying lesion と正常部に ROI を設定することに より血流状態の差も曲線として描記できる. 経時的腎イ メージは移植腎の腎機能検査, 腎血管性高血圧症の診断 にも有用である。

最後に ${ }^{99 \mathrm{~m}} \mathrm{Tc}$ - $(\mathrm{Sn}) \mathrm{DTPA}$ と ${ }^{131} \mathrm{I}$-Hippuran のレノグラ ムと腎イメージの特徵をまとめると Table. 1 の如く になる. 正常例では, ${ }^{99 \mathrm{~m} T c-(\mathrm{Sn}) \mathrm{DTPA} レ}$ レグラムは
${ }^{131}$ I-Hippuran レノグラムと比較し曲線は緩徐である。 腎実質イメージは ${ }^{99 \mathrm{~m}} \mathrm{Tc}$-(Sn)DTPA では3〜6分ま で, ${ }^{131} \mathrm{I}$-Hippuran では 3 分までが鮮明である. 閉塞性 腎疾患では両レノグラムはともに閉塞型を示し, 両イメ 一ジは腎孟部への著明な RI 集積 (centralization)を示

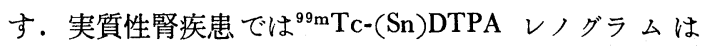
第 2 相の消失, 平低化を示すのに反し, ${ }^{131}$ I-Hippuran レノグラムは第 2 相の平低化との第 3 相の遅延を示す ものと, 閉塞型を示す 2 つの型式汸ある. ${ }^{99 \mathrm{~m}} \mathrm{Tc}-(\mathrm{Sn})$ DTPA と ${ }^{131}$ I-Hippuran の経時的腎イメージは均等で あるが, ${ }^{131}$ I-Hippuran レノグラムが閉塞型を示するの は時間経過とともに腎イメージは鮮明となる。従つて

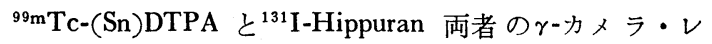
ノグラムを同時に施行することによつて，2つの側面か ら腎機能 (動態) の観察が可能で, 腎疾患の鑑別にも役 立つであるう。

\section{結 論}

1） $\gamma$-カメラと新しい放射性医薬品 ${ }^{99 \mathrm{~m} T \mathrm{Tc}-(\mathrm{Sn}) \mathrm{DTPA}}$ 
（GFR 物質）を用いたレノグラム（ $\gamma$ ーカメラ・レノグ ラム) の有用性を検討した。

2）対象は 186症例（男子96例，女子90例）で,これ

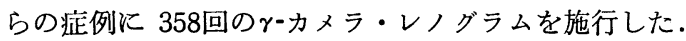

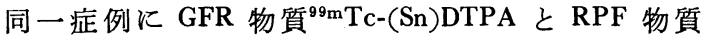
${ }^{131}$ I-Hippuran の併用によるr-カメラ・レノグラム括よ び経時的腎イメージを 154症例に 326回実施した。

3） $\boldsymbol{\gamma}$-カメラ・レノグラムは左右両腎部に正確にROI を設定、レノグラムを描出するので在来のレノグラム でしばしばみられたような腎の位置ずれがなく，大動脈 など腎以外の放射能の影響をも受けない利点がある。ま た，同時に行なら経時的腎イメージから腎の形態や排泄 動態に関する情報も得られる。

4） ${ }^{99} \mathrm{~m} \mathrm{Tc}-(\mathrm{Sn}) \mathrm{DTPA}$ は安定した放射性化合物で, GFR物質としては腎からの排泄も比較的早く ${ }^{131}$ I-Hippuran 飞劣らず腎動態機能検査に適している。また， ${ }^{131} \mathrm{I}$ Hippuran レノグラムでは実質性腎障害時にも閉塞型レ ノグラムを示すことがあるが， ${ }^{99 \mathrm{~m} T c-(S n) D T P A ~ レ ノ ク ゙ ~}$ ラムが閉塞型レノグラムを示さないときは閉塞性腎障 害ではなく実質性腎障害が主体であることを見出した。

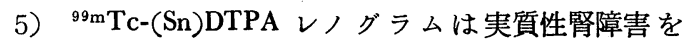

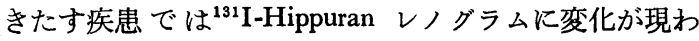
れる前に異常が現われる。 また，上部尿路の尿流障害緩 解期では, ${ }^{99} \mathrm{~m} \mathrm{~T}$ c-(Sn)DTPA レノグラムの改善は ${ }^{131} \mathrm{I}$ Hippuran レノグラムより遅れる。すなわち, ${ }^{99 \mathrm{~m} T c-~}$ (Sn)DTPA レノグラムは上部尿路に通過障害をきたす疾 患の術後の腎実質機能回復の経過観察に役立つ.

6） $\gamma$-カメラ・レノグラムは分腎機能検査法として鋭 敏で被検者の負担も軽く, 高齢者や重症患者にも容易に 施行でき, 腎の動態機能, 経時的形態の変化を検査する 優れた方法である。

なお，本論文の要旨は第13，14回日本核医学会総会， 第 2 回日本核医学会関東甲信越地方会，第348，351回日 本泌尿器科学会東京地方会, 第15,16回日本老年医学会 総会で報告した。

$$
\text { 文献 }
$$

1）金子昌生,佐々木常雄：Radioisotopes，17，317,
1968.

2) 岸本 孝, 小峰志訓, 石川大二 : 日泌尿会誌, 60, 61, 1965.

3) 三木 誠, 町田豊平, 上田正山，木戸 晃，南 武, 森 瑞樹, 小塚勝義：日泌尿会誌, 64, 163，1973.

4) 上田英雄, 飯尾正宏 : 核医学臨床生理診断法, 第 1 版，438,医歯薬出版，東京，1973.

5) 上田正山, 三木 誠, 町田豊平, 南 武, 三 浦義幸, 山田裕史, 田中彰, 浦久保五郎 : Radioisotopes, 21, 566, 1972.

6) Klopper, J.F., Hauser, W., Atkins, H.L., Eckelman, W.C. and Richards, P.: J. Nucl. Med., 13, 107, 1972.

7) Atkins, H.L., Cardinale, K.G., Eckelman, W.C., Hauser, W., Klopper, J.F. and Richards, P.: Radiology, 98, 674, 1971.

8) Hine, G.J. and Johnston, R.E.: J. Nucl. Med., 11, 469, 1970.

9) Lieberman, E.: Personal communication.

10) Konikowski, T., Glenn, H.J. and Haynie, T.P.: J. Nucl. Med., 13, 834, 1972.

11) Winter, C.C.: J. Urol., 85, 683, 1961.

12) Trinkle, J.K. and Kiser, W.S.: J. Urol., 91, 199, 1964.

13) Mayo, M.E., Hilton, P.J., Jones, N.F., LloydDavies, R.W. and Croft, D.M.: Brit. Med. J., 3, 516, 1971 .

14) Wax, S.H. and McDonald, D.F.: J. Urol., 96, 816, 1966.

15) Zum Winkel, K.: 核医学, 9, 303, 1972.

16) Loken, M.K., Staab, E.W., Vernier, R.L. and Kelly, W.D.: J. Nucl. Med., 5, 807, 1964.

17）高安久雄, 岩本 孝, 阿曽佳郎, 小川秋実, 北 川竜一, 上野 精, 小磯謙吉, 加納勝利: 日本 臨床, 26, 2334, 1968.

18）大石幸彦, 千葉一夫, 松井謙吾, 山田英夫, 入 倉英雄, 飯尾正宏, 南武, 町田豊平 : 核医 学, 11, 541，1974.

19）久田欣一，利波紀久：臨床放射線，13，920, 1968.

20) Hayes, M., Swanson, L.A. and Taplin, G.V.: J. Nucl. Med., 7, 337, 1966.

(1976年 2 月 5 日受付) 